\section{$\Omega$}

Kuraos

\title{
Evaluasi terhadap Tata Ibadah Kontekstual Gereja Kristen Jawa
}

\author{
Ayub Widhi Rumekso \\ Fakultas Theologia, Universitas Kristen Surakarta \\ rumekso@gmail.com
}

\begin{abstract}
The worship of the people of the Javanese Christian Church cannot be separated from the liturgy. The liturgy gives an introduction, views, and attitudes of the Christian faith to the Javanese Christian Church amid its existence. Throughout the history of the MPD liturgies, the I, II, III, and lectionary variations of the I and II liturgical models have been developed. The process of birth and development of the GKJ liturgy are important elements of research to find an explanation, why GKJ people still have a distance from the realities of life that exist in society. The results found in this study indicate that the GKJ liturgy that has been built has not been placed on the reality of the struggle and hopes of the people amid community and cultural life. The current GKJ's view of the liturgy has a similar meaning to the religious rituals of the people that shape the identity of the people, but there is no critical step capability to build up their worship with praxis so that it can be lived in and have an impact on the lives of the people and the community.
\end{abstract}

\begin{abstract}
Abstrak
Peribadahan umat Gereja Kristen Jawa tidak bisa dilepaskan dari liturgi. Liturgi memberikan pengenalan, pandangan, serta sikap iman Kristen kepada umat Gereja Kristen Jawa di tengah keberadaannya. Sepanjang sejarah liturgi GKJ telah dikembangkan model liturgi GKJ formula I, II, III, dan leksionari variasi I dan II. Proses kelahiran dan pengembangan liturgi GKJ merupakan unsur-unsur penting penelitian dalam rangka mencari penjelasan, mengapa umat GKJ masih memiliki jarak dengan kenyataan kehidupan yang ada di tengah masyarakat. Hasil yang ditemukan dalam penelitian ini memperlihatkan bahwa liturgi GKJ yang telah dibangun belum diletakkan pada kenyataan pergumulan dan harapan umat di tengah kehidupan masyarakat dan budayanya. Pandangan GKJ masa kini tentang liturgi memiliki persamaan makna dengan ritual keagamaan masyarakat yang membentuk jatidiri umat, tetapi belum ada kemampuan langkah kritis konkrit untuk membangun tata peribadahannya dengan praksis sehigga dapat dihayati dan memberikan dampak bagi kehidupan umat maupun masyarakatnya.
\end{abstract}

Article History

Submit:

09 March 2019

Revised:

05 April 2019

Accepted:

30 April 2019

Keywords

(kata kunci):

contextual

worship; liturgy;

management of service;

Javanese

Christian

Church;

ibadah

kontekstual;

liturgy;

tata ibadah;

Gereja Kristen Jawa;

masyarakat Jawa

\section{Pendahuluan}

Sebagai salah satu penerus tradisi Gereja Reformasi, Gereja Kristen Jawa (GKJ) memiliki ajaran iman yang sangat mendasar sehubungan dengan keberadaannya. Ajaran resmi yang dituangkan di dalam Pokok-Pokok Ajaran Gereja Kristen Jawa (PPAGKJ) menyatakan 
bahwa keberadaannya merupakan buah penyelamatan Allah. Penyelamatan Allah itu memungkinkan manusia untuk memiliki kembali hubungan yang benar dengan Allah. Hubungan dengan Allah ini sering disebut juga dengan istilah keselamatan. ${ }^{1}$

Selanjutnya, untuk mengungkapkan apa yang menjadi dasar keberadaannya itu, GKJ melakukan suatu tindakan yang disebut dengan istilah ibadah. Segala sesuatu dalam ibadah tersebut dipahami menjadi gambaran pertemuan dan percakapan timbal balik antara umat dengan Allah. Bagi GKJ ibadah dipandang sebagai tindakan dramatis simbolis. ${ }^{2}$ Adapun pokok-pokok yang ada di dalam pertemuan dan percakapan di atas pada akhirnya juga menjadi garis besar dan sekaligus dasar perumusan tata peribadahan (liturgi) yang tersusun secara urut dan teratur, yaitu adiutorium (pertolongan Allah, yang terjadi dalam ibadah) atau votum (seruan peng-absahan terjadinya ibadah, oleh karena pertolongan Allah) dan salam, introitus (pengantar untuk memulai ibadah) dan pujian, pengakuan dan penyesalan dosa, berita anugerah dan petunjuk hidup baru, kesanggupan, doa syukur dan syafaat, persembahan, pelayanan sabda, pengakuan iman, pengutusan, dan berkat. ${ }^{3}$

Oleh karena liturgi di dalam ibadah GKJ berisikan gambaran pokok-pokok pertemuan dan percakapan antara umat dengan Allah, maka liturgi di sini sesungguhnya dapat dipahami pula sebagai gambaran yang menghadirkan kembali ingatan akan pusat sekaligus sumber ibadah dari GKJ itu sendiri, yaitu penyelamatan yang telah dilakukan oleh Allah yang berpuncak pada pengorbanan Yesus Kristus. Makna-makna pengorbanan Yesus Kristus tersebut merupakan satu kesatuan dari karya penyelamatan Allah bagi umat dengan lambang perjamuan dan baptisan sebagai sakramen. Sebagaimana dinyatakan pada PPAGKJ bahwa makna yang terdapat pada Sakramen Perjamuan dan Sakramen Baptisan sebagai inti dari liturgi men-jadi sesuatu yang dikuduskan (Jawa, kang sinengker) untuk dipersembahkan kepada Allah yang berguna di dalam pekerjaan penyelamatan Allah, khusus-nya sisi pemeliharaan iman umat. ${ }^{4}$ Pemahaman itu dipertegas pula dalam PPAGKJ Edisi 2005 yang menyatakan bahwa sakramen adalah alat pelayanan yang dikhususkan di dalam pekerjaan penyelamatan Allah, yaitu sebagai penyataan dan pemeliharaan iman. ${ }^{5}$

Dengan seluruh pemahaman di atas, maka liturgi dalam ibadah GKJ dapat dimengerti bukan sekedar tindakan upacara keagamaan (ritual) belaka. Liturgi di dalam peribadahan sesungguhnya merupakan "jiwa" kepercayaan rohani atau keimanan GKJ yang memiliki hubungan erat dan tidak terpisahkan dengan karya tanggung jawab agung dari Illahi dalam kehidupan nyata di dunia ini. Malcolm Brownlee menyatakan bahwa peribadatan yang terdapat di dalam Alkitab dengan segala unsurnya tidak terpisahkan dari kehidupan seharihari. Hubungan erat tersebut nampak dari beberapa istilah yang dipakai oleh Alkitab, yaitu "sharath" dan "abodah" dalam Perjanjian Lama, serta "latreia" dan "leitourgia" dalam Perjanjian Baru, yang artinya "kebaktian”, “pelayanan”, "kerja”, yang artinya mirip dengan

\footnotetext{
${ }^{1}$ Sinode GKJ, Pokok-Pokok Ajaran Gereja Kristen Jawa (Salatiga: Percetakan Sinode GKJ, 1998), $18,36$.

${ }^{2}$ Ibid., 51-52.

${ }^{3}$ Sinode GKJ, Liturgi Gereja Kristen Jawa (Salatiga: Percetakan Sinode, 1996), 10-21.

${ }^{4}$ Sinode GKJ, Pokok-Pokok Ajaran Gereja Kristen Jawa, 55.

${ }^{5}$ Sinode GKJ, Pokok-Pokok Ajaran Gereja Kristen Jawa Edisi 2005 (Salatiga: Per-cetakan Sinode GKJ, 2009), 47.
} 
makna kata "pengabdian". ${ }^{6}$ Brownlee juga menegaskan bahwa peribadatan orang Kristen tidak terbatas kepada upacara-upacara tertentu, melainkan dilakukan di dalam semua segi kehidupan.

Selain pengertian dari sisi "jiwa" kepercayaan rohani atau spiritualitas, liturgi dalam ibadah GKJ juga mengandung pengertian adanya sisi karya tugas penting yang diemban umat sebagai pengutusan bagi kehidupan di tengah dunia ini. Sebagaimana dijelaskan oleh Rasid Rachman, bahwa berdasarkan liturgi yang ada dalam tradisi gereja kuno maka ibadah bagi Gereja bukanlah semata-mata tujuan, melainkan juga sebuah pengutusan. ${ }^{7}$ liturgi dalam ibadah memiliki makna yang berguna untuk memampukan Gereja agar dapat menampakkan tanda-tanda Kerajaan Allah yang hadir di tengah dunia, sebagai wujud penyelamatanNya secara nyata. ${ }^{8}$

Berdasarkan pengamatan tersebut di atas, perlu dipertanyakan lebih lanjut, sejauh manakah praktik liturgi dalam ibadah GKJ dapat terlaksana secara baik sesuai dengan kegunaannya. Apakah liturgi yang selama ini ada dan berlaku dalam ibadah GKJ telah dapat menjadi sarana penghayatan umat untuk beribadah sebagaimana mestinya, meskipun bentuknya sederhana? Di dalam pelaksanaannya, unsur-unsur yang ada di dalam liturgi cenderung masih banyak dipahami sebagai tata urutan di dalam peribadahan yang tidak lebih dari sebatas tata perilaku rohani atau ritual umat di tengah ruangan tertentu yang kurang, atau bahkan tidak memiliki hubungan serta berbeda dengan kehidupan dunia sehari-hari.

Suasana ini terasa pada ketegangan yang terdapat di dalam perjumpaan kehidupan kultural umat sehari-hari berdasarkan nilai-nilai yang berlaku di tengah Gereja sebagai komunitasnya dengan berbagai bentuk tata nilai masya-rakat maupun adat istiadat yang merupakan gambaran pandangan budaya di mana umat tersebut hidup dan tumbuh di dalamnya. Peribadahan dengan liturgi yang dijalankan seakan menjadi tidak ber-sentuhan dan tidak tersentuh sama sekali oleh tata nilai kehidupan sesungguhnya dari masyarakat yang menjadi kenyataan hidup sehari-hari umat. Adapun tujuan dari lakukannya penelitian ini adalah untuk melakukan analisa kritis dengan menggunakan pendekatan teologi kontekstual terhadap tata peribadahan GKJ berbasis budaya Jawa seperti apa yang ada di dalam dokumen gerejawi secara sinodal terkait dengan liturgi.

\section{Prinsip liturgi GKJ Terkait Liturgi Variasi maupun Liturgi Pelayanan Khusus}

Adanya pokok-pokok bagian yang terangkai menjadi perwujudan makna pertemuan antara Tuhan dan umatNya dengan dialog yang merupa-kan bentuk keterlibatan umat di dalam kedua liturgi baru tersebut me-nunjukkan adanya persamaan-persamaan yang mengacu pada pengakuan prinsipial liturgi seperti penjelasan ringkas pokok-pokok bagian liturgi GKJ berikut ini. ${ }^{9}$

\footnotetext{
${ }^{6}$ Malkolm Brownlee, Tugas Manusia dalam Dunia Milik Tuhan: Dasar Teologis bagi Pekerjaan Orang Kristen dalam Masyarakat (Jakarta: BPK Gunung Mulia, 1989), 19.

${ }^{7}$ Rasid Rachman, Pembimbing ke dalam Sejarah Liturgi (Jakarta: BPK Gunung Mulia, 2010), 5.

${ }^{8}$ Sinode GKJ, Pokok-Pokok Ajaran Gereja Kristen Jawa, 37.

${ }^{9}$ Sinode GKJ, Liturgi GKJ, 10-14.
} 
Votum (Adiutorium), berarti janji yang khidmat atau ikrar. Pelaksanaan bagian ini selalu ada di awal peribadatan. Sebab votum berisikan rumusan untuk meneguhkan pengabsahan peribadatan yang dilaksanakan. Sumber yang diambil untuk rumusan votum adalah Mazmur 124:8, maupun Mazmur 138, atau Mazmur 146:6. Akan tetapi, yang diguna-kan biasanya adalah Mazmur 124:8 saja, seperti yang diwajibkan oleh Sinode Dordrecht (1574) dari kebiasaan Calvin. Rumusan votum itu ialah, "Pertolongan kita adalah dalam nama Tuhan yang menjadikan langit dan bumi." Karena peneguhan di sini menyatakan pengakuan adanya per-tolongan, maka votum disebut juga adiutorium, yang artinya pertolongan. Pelaksanaan votum di dalam bahasa Jawa dapat diucapkan dengan "ngoko" ataupun "krâmâ".

Salam. Sumber untuk rumusan salam GKJ adalah salam rasuli (Roma 1:7 ; I Korintus 1:3, dst.), yang diambil dari adat kebiasaan peribadatan Yahudi (Immamat 19:20; I Samuel 25:6). Bagian ini terangkai dengan votum. Pelaksanaan salam dilakukan oleh pemimpin peribadatan setelah votum, dengan mengangkat tangan kanan lurus ke atas. Sesuai keputusan Sinode GKJ, salam disampaikan dengan mengangkat tangan hanya apabila yang melayankan pendeta. Apabila yang melayankan bukan pendeta, tidak dengan mengangkat tangan.

Pujian, yaitu pemuliaan Tuhan dengan nyanyian atau dibarengi dengan bacaan Mazmur; Bagian ini sebenarnya biasa disebut introitus, yang terdiri dari nyanyian masuk dengan, atau tanpa nats pendahuluan sebagai pem-bimbing. Nats pembimbing harus sesuai dengan khotbah. Nyanyian pujian sebagai jawab jemaat.

Pengakuan Dosa. Pengakuan dosa terdiri lima bagian. (1) Pembacaan Hukum Kasih. (2) Setelah menerima Hukum Kasih, jemaat mengakui dan menyesali dosanya dengan doa atau nyanyian penyesalan, bahkan keduanya. (3) Sesudah itu, jemaat menerima berita anugerah pengampunan dari Alkitab. (4) Setelah menerima pengampunan dosa, jemaat masuk ke dalam persekutuan hidup baru di dalam Tuhan Yesus Kristus. Oleh karena itu, jemaat diberi petunjuk atau perintah hidup baru dari Alkitab. Kalau menurut Calvin tahap ini dibacakan Sepuluh Hukum. Itu bukan untuk cermin mengetahui dosa, tetapi berisi petunjuk-petunjuk menurut perintah Tuhan, agar orang yang telah diperbaharui hidupnya menjadi anak-anak Tuhan, yang dapat mengetahui dan mentaati kehendak Tuhan. (5) Kesanggupan, yang menjadi wujud jemaat yang sudah bergembira di dalam persekutuan Tuhan Yesus Kristus dengan seruan tekat berwujud komitmen dan nyanyian yang tepat.

Doa. Doa di sini adalah doa syukur dan doa syafaat. Supaya tidak terlalu panjang, berputar-putar, dan diulang-ulang, maka di dalam doa ini pelayan harus menentukan apa saja yang didoakan. Dalam doa ini tidak dimasukkan doa untuk pengampunan dosa, sebab sudah dilakukan sebelumnya di dalam bagian pengakuan dosa. Doa ini juga bisa dilakukan oleh pelayan dan jemaat. Misalnya: Doa syukur untuk permulaan doa itu disampaikan oleh pemimpin lalu disambung dengan syafaat yang dilakukan oleh beberapa anggota jemaat atau penatua. Tentu saja ditunjuk lebih dulu siapa yang berdoa untuk hal ini, dan seterusnya. Kemudian ditutup oleh pelayan.

Persembahan. Bagian ini terdiri dari tiga bagian. (1) Pembacaan ayat-ayat dari Alkitab untuk mendorong, atau dasar dan tujuan persembahan. (2) Pengumpulan persembahan. (3) 
Doa untuk menghaturkan persembahan yang sudah terkumpul kepada Tuhan. Hal ini boleh juga dilakukan oleh anggota majelis. Dan dalam doa itu disambung juga dengan doa untuk pelayanan Firman yang segera akan dilakukan.

Pelayanan Firman. Pokok bagian ini terdiri dari tiga bagian. (1) Pem-bacaan Firman dari Alkitab. (2) Pembacaan nats Khotbah. (3) Khotbah. Setelah pelayanan Firman, selanjutnya adalah pokok bagian Penutup. Dalam pokok bagian penutup, ada dua hal. (1) Doa penutup, dan lebih baik bila doa ini diakhiri dengan Doa Bapa kami. (2) Nyanyian penutup.

Sebelum pelayanan berkat ada pokok bagian lain, yaitu Pengakuan Iman. Pokok bagian ini diucapkan bersama-sama oleh seluruh jemaat, bukan hanya pelayan sendiri, dengan cara berdiri. Selesai pelaksanaan Pengakuan Iman, yang terakhir adalah pokok bagian Berkat. Sumber yang diambil untuk rumusan berkat adalah Bilangan 6:24-26, atau dapat juga dari II Korintus 13:13.

Hal yang tidak kurang penting ialah bahwa pada permulaan ibadah, wakil majelis jemaat menyerahkan Alkitab kepada pelayan, dan pada akhir ibadah, wakil majelis yang tadi menyerahkan Alkitab kepada pelayan kemudian menerima kembali Alkitab tadi dari pelayan. Ini melambangkan pemberian mandat untuk melayani ibadah (termasuk di dalamnya penyampaian ajaran) sesuai dengan Firman Tuhan dan pada akhir ibadah mandat tersebut dikembalikan lagi.

Jadi, penanganan persoalan yang berasal dari tantangan-tantangan pelaksanaan liturgi GKJ di atas adalah berupa pemberian pengertian mau-pun teknis pelaksanaan agar mudah disampaikan kepada umat, sekaligus dapat dipelajari dan dipraktikan oleh mereka. Bisa jadi persoalan ini mirip dengan apa yang dilakukan oleh umat Kristen pra-GKJ dengan serangkaian ritual persiapan saat hendak hingga memasuki peribadahan menurut cara yang mereka terima dan hayati sebagai orang Jawa. Itu artinya, persoalan liturgi sebagai cara penghayatan iman umat bukanlah pekerjaan sambil lalu, melainkan harus ada tanggung jawab penyampaian yang dikerjakan khusus.

\section{Perkembangan Pergumulan Liturgi GKJ Baru}

Terbitnya buku Liturgi GKJ dengan muatan yang memadai tersebut menjadi awalan baru bagi kehidupan peribadatan umat GKJ. Hingga kini, kiranya secara berangsur-angsur formula-formula liturgi yang terhimpun di dalam buku Liturgi GKJ itu mampu mendorong umat GKJ semakin dapat terbuka untuk menyadari dan mengerti akan inti penghayatan iman yang harus diwujudkan melalui dan sekaligus sebagai ibadah kepada Tuhan di tengah kenyataan kehidupan dunia di mana dia berada.

Menurut data yang dapat dicermati, terdapat dua sisi kenyataan kehidupan dunia yang mendorong perkembangan di dalam pergumulan pelaksanaan liturgi GKJ lebih lanjut. Sisisisi itu adalah kesadaran akan kebutuhan yang berasal dari pergumulan kehidupan umat GKJ di aras jemaat setempat (lokal) dan sinodal (oikumenikal), terkait dengan kenyataan kemasyarakatan yang bersifat majemuk beserta dengan berbagai macam kebudayaan yang ada di dalamnya. 
Kesadaran-kesadaran akan kebutuhan yang berasal dari pergumulan kehidupan umat GKJ di aras lokal maupun sinodal tersebut sebetulnya bukanlah sesuatu yang sama sekali baru. Tetapi seiring dengan proses waktu, jaman, maupun kenyataan kemasyarakatan yang terus berubah dan sungguh berbeda, secara pasti GKJ mulai melepaskan diri dari ketergantungannya terhadap faham-faham yang dimiliki oleh Gereja inangnya, yaitu Heidelbergsche Catechismus. GKJ mulai berusaha memandang ber-bagai kenyataan yang ada di tengah keberadaannya sebagai pijakan sekaligus tempat untuk mewujudkan iman yang membumi. $^{10}$

\section{Kesadaran Akan Kebutuhan dari Pergumulan Umat GKJ di Aras Jemaat Lokal}

Semenjak diberlakukannya Liturgi GKJ baru, pada tahun 1996 mulai nampak adanya pergumulan atas perjumpaan iman umat GKJ yang senan-tiasa diresapi melalui liturgi dengan kenyataan budaya yang setiap hari ada di tengah kehidupan masyarakatnya. Perjumpaan itu makin menyadarkan umat akan kebutuhan budaya sebagai ruang bagi mereka bertumbuh sekaligus mewujudkan imannya di dalam kehidupan nyata. Karena itu, pada Sidang Sinode Terbatas GKJ 1996 dinyatakan bahwa: "Setelah membahas rekomendasi Aktuarius tentang perlunya setiap keluarga warga GKJ ikut memelihara dan melestarikan budaya serta bahasa Jawa, sidang memutus-kan agar warga GKJ terlibat secara kritis dalam kegiatan pelestarian budaya dan bahasa Jawa dalam kehidupan sehari-hari di keluarga maupun dalam kebaktian, dengan cara antara lain menggunakan renungan harian dalam bahasa Jawa."11

Seiring dengan perubahan yang ada di tengah masyarakatnya, seakan bahasa Jawa mulai terpinggirkan oleh bahasa Indonesia. Karena tetap dipandang penting, maka keputusan Sidang Sinode Terbatas GKJ 1996 itu menjadi penggiat bagi umat GKJ menumbuhkan dan mempergunakannya kembali. Demikian juga dengan gamelan yang dulu dikesampingkan dari peribadatan karena belum bisa dianggap punya nilai kristiani, ${ }^{12}$ maka dengan keputusan Sidang Sinode Terbatas GKJ 1996 ter-sebut memiliki peluang besar untuk dipergunakan sebagai mana mestinya.

Secara mendasar, contoh-contoh di atas memberikan pengertian pula bahwa sisi-sisi budaya lainnya di dalam kemajemukan masyarakat yang ada di tengah kehidupan umat GKJ memiliki peluang juga untuk dijadikan pijakan sekaligus tempat bagi pewujudan iman yang mengakar; termasuk ungkapan iman melalui liturgi. Karena itulah, di dalam proses pergumulan lanjutan tentang Liturgi GKJ baru, selain diadakan upaya sosialisasi hasil kajian liturgi dan nyanyian gerejawi pada persidangan Sinode Antara GKJ 2004 diadakan sarana penunjang bagi kebutuhan yang dipergumulkan di aras lokal itu, yaitu: Pelatihan Bahasa Jawa, pembentukan Wadah Konsul-tasi Bahasa dan Budaya Jawa. ${ }^{13}$

Kebutuhan dari pergumulan aras lokal umat GKJ tersebut nyata dengan adanya berbagai upaya tindak lanjut yang (secara langsung ataupun tidak langsung dapat dikaitkan dengan

\footnotetext{
${ }^{10}$ Sinode GKJ, Pokok-Pokok Ajaran Gereja Kristen Jawa Edisi 2005, (Salatiga: Percetakan Sinode GKJ, 2009), vii-x.

${ }^{11}$ Akta Sidang Sinode GKJ Terbatas 1996 Artikel 41.

${ }^{12}$ Lih., Acta Synode Poerwokerto 1936, no. 13.

${ }^{13}$ Akta Sidang Sinode GKJ Antara 2004 Artikel 25, 26, 27.
} 
liturgi) menjangkau banyak segi yang berasal dari keberadaan masyarakat beserta dengan budaya yang ada di dalamnya. Perluasan jangkauan segi-segi keberadaan masyarakat beserta dengan budayanya itu meliputi pembentukan Tim Liturgi dan Musik Gereja-wi maupun Komisi Liturgi, Lembaga Kajian Budaya Jawa (LEMKABUJA), mengadakan kajian teologi kontekstual dan berteologi lokal serta teologi bencana, kajian agama-agama maupun hubungan dialogis dan kerja sama dengan penganut agama lain, teologi lintas iman, Studi Intensif Tentang Islam (SITI), kajian Pancasila sebagai asas bernegara dan berbangsa di Indonesia, kajian jender, kajian lingkungan hidup, ${ }^{14}$ dan lain sebagainya.

Terkait dengan perluasan pemahaman dan pengungkapan iman di awal sebelum adanya Liturgi GKJ Baru tersebut, terdapat dua keputusan penting dari Sidang Sinode GKJ IX tahun 1964 ini. Yang pertama dinyatakan bahwa: "Setelah membahas laporan Komisi Kebudajaan Nasional yang berisi (1) Anggota Komisi terdiri dari 7 orang, (2) Susunan organisasi komisi jang lalu terdiri dari ketua, penulis, anggauta, ditambah Seksi Tata Panembah, Seksi Mazmur/Kidung, Seksi Karawitan/Beksan/Pedalangan, (3) Hasil pekerdjaan seksi, antara lain: tjeramah, ekspresi kebudajaan nasio-nal, dan lain sebagainja, sinode memutuskan menerima baik laporan-laporan tersebut, serta usul-usulnya dengan ketentuan (1) Membentuk Deputat Kebudajaan jang tetap dengan seksi-seksi penelitian dan penggiat. Deputat diberi tugas: a) Mengadakan penelitian terhadap perkembangan di bidang kebudajaan, b) Memberikan pandangan-pandangan tentang kebudajaan, c) Menggiatkan lembaga-lembaga kebudajaan Kristen jang ada agar dapat dipimpin kepada pertobatan dan kemurnian kebudajaan nasional jang menuju kepada ethos dan escathos Keradjaan Surga, d) Membentuk Panitia Kebudajaan di tiap djemaat, e) Berusaha menjediakan anggaran belandja jang tjukup untuk melaksanakan tugas tersebut." 15

Yang kedua dinyatakan bahwa: "Dalam membitjarakan usul Klasis Sala Timur mengenai penindjauan kembali Pengadjaran Agama Kristen (Heidelbergsche Catechismus), mengingat (1) Kebutuhan menjelaraskan pengadjaran agama dengan keadaan jang terdapat di Indonesia pada umumnja, dan suku Djawa pada chususnja jang menganut aliran Islam dan Kedjawen (mistik), (2) Bahwa Heidelbergsche Catechismus diterima sebagai keterangan tentang Firman Tuhan dalam Perdjanjian Lama dan Baru dalam lingkungan GKD, (3) Memandang penting bahwa Pengadjaran Agama Kristen perlu diberikan dengan mengingat latar belakang keagamaan masyarakat, sinode memutuskan memberi tugas kepada Deputat Penjelidikan untuk: a) Mempeladjari Heidelbergsche Catechismus, apakah membutuhkan perubahanperubahan atau tambahan-tambahan berhubung dengan kepentingan di atas, b) Mengusulkan perobahan dan tambahan-tambahan kepada Sinode, bilamana dipandang perlu, c) Melaporkan hasil penjelidikan tersebut kepada sindang Sinode jang akan datang.",16

${ }^{14}$ Akta Sindang Sinode GKJ XXI 1994 Artikel 110, 111, 112., Akta Sindang Sinode GKJ Terbatas 1996 Artikel 41, 49, 63., Akta Sindang Sinode GKJ Antara 2000 Artikel 11., Akta Sindang Sinode GKJ XXIII 2002 Artikel 22, 35., Akta Sindang Sinode GKJ Antara 2004 Artikel 67., Akta Sindang Sinode GKJ XXIV 2006 Artikel 11, 18, 44, 67., Akta Sindang Sinode GKJ XXV 2009 Artikel 15, 16, 17, 43, 56., Akta Sindang Sinode GKJ XXVI 2012 Artikel 18, 48, 55, 62.

${ }^{15}$ Acta Sindang Sinode GKD IX 1964 Artikel 83.

${ }^{16}$ Acta Sidang Sinode GKD IX 1964 Artikel 87. 


\section{Kesadaran akan Kebutuhan dari Pergumulan Umat GKJ di Aras Sinodal}

Apabila wujud sisi kesadaran akan kebutuhan dari pergumulan umat GKJ di aras lokal di atas bersifat gagasan-gagasan mendasar berlandaskan budaya sebagai cara pandang di dalam kehidupan peribadatan, maka pada kesadaran akan kebutuhan dari pergumulan umat GKJ di aras sinodal di sini cenderung lebih bersifat atributif dan teknis dalam menyampaikan sumber yang digunakan sebagai wahana untuk menghantarkan gagasan-gagasan dasar beserta nilainilainya bagi kehidupan umat melalui pengajaran (khotbah). Demikian pula, bahwa kesadaran akan kebutuhan dari per-gumulan umat GKJ pada aras sinodal di sini juga memiliki sifat pastoral.

Seperti dinyatakan dalam Akta Sidang Sinode GKJ XXI 1994 Artikel 30 bahwa: "Setelah membahas laporan Deputat Keesaan Sinode GKJ XX tentang pemakaian toga bagi para pendeta GKJ, dengan memperhatikan dan mempertimbangkan bahwa pendeta mempunyai pakaian jabatan yaitu toga dan clerical colar, sidang memutuskan untuk upacara-upacara khusus antara lain pelayanan sakramen, peneguhan, diseyogyakan para pendeta mengena-kan toga, sedangkan untuk acara/keperluan lain menyesuaikan.” Dari per-nyataan tersebut jelas sekali bahwa pakaian pendeta merupakan lambang liturgis yang dianggap penting dan dibutuhkan umat di dalam pelaksanaan pelayanan peribadatan.

Untuk menegaskan kebutuhan ini, pergumulan pakaian pendeta sebagai lambang liturgis tersebut ditindaklanjuti pada Sidang Sinode GKJ Non Reguler tahun 2005. Dalam Artikel 14 dinyatakan bahwa: "Setelah membahas Draft Tata Gereja dan Tata Laksana GKJ tentang pakaian liturgis pendeta GKJ dan kelengkapannya, antara lain berupa toga dan stola, sidang memutuskan (1) Menugasi Lembaga Studi dan Pengembangan (LSP) GKJ melalui Deputat Keesaan untuk: a) Melakukan studi tentang pakaian liturgis yang mencakup i) Sejarah penggunaan pakaian liturgis, ii) Dasar teologis dan makna. b) Melaporkan hasil studi tersebut ke Sidang Sinode GKJ XXIV. (2) Menugasi Deputat Penatalayanan untuk menganggarkan biaya studi tersebut."

Hasil dari kerja LSP GKJ yang diputuskan dalam Sidang Sinode GKJ Non Reguler 2005 tersebut tertuang pada Akta Sidang Sinode GKJ XXIV 2006 Artikel 26 yang menyatakan bahwa: "Setelah membahas materi dari Klasis Sragen dan laporan LSP Sinode GKJ tentang penggunaan simbol-simbol dan pakaian liturgi, sidang memutuskan (1) Menerima laporan LSP. (2) Tetap memberikan kebebasan Majelis Gereja untuk memutuskan peng-gunaan simbol-simbol lokal serta pakaian lokal dalam ibadah. (3) Menugasi BAPELSIN untuk menyusun pedoman penggunaan simbol-simbol dan pakaian liturgi beserta maknanya serta menjemaatkan ke Gereja-Gereja."

Masih berhubungan dengan pergumulan lambang liturgis di dalam peribadatan umat GKJ yang lainnya adalah pengangkatan tangan. Setelah pemberlakuan Liturgi GKJ baru, pergumulan tentang pengangkatan tangan di dalam salah satu pokok bagian yang terdapat pada awal dan akhir liturgi terungkap pada Akta Sidang Sinode GKJ XXIV 2006 Artikel 22. Pada artikel itu dinyatakan bahwa: "Setelah membahas materi dari Klasis Salatiga tentang pengangkatan tangan oleh pejabat gerejawi selain Pendeta dalam ibadah ketika salam dan 
berkat, sidang memutuskan menugasi BAPELSIN untuk melakukan pengkajian tentang hal ini, dengan memperhatikan Akta Sidang Sinode GKJ XIII tahap II/1974 Artikel 153."17 Selanjutnya karena dianggap belum tuntas dan penting bagi peribadatan umat GKJ pada umumnya, maka muncul lagi dalam Akta Sidang Sinode GKJ XXVI 2012 Artikel 91, yang menyatakan bahwa: "Setelah membahas materi dari Klasis Salatiga Utara tentang pernah adanya penugasan kepada LSP untuk meng-kaji pengangkatan tangan non Pendeta dalam ibadah namun belum pernah ada publikasinya; sidang memper-timbangkan Akta Sidang Sinode XXIV 2006 Artikel 22 tentang pengangkatan tangan dalam ibadah, sidang memutuskan menugasi BAPELSIN GKJ XXVI melakukan kajian dikaitkan dengan teologi jabatan serta menjemaatkan."

Kebutuhan dari pergumulan umat akan persoalan itu nyata seperti ter-gambar dalam pernyataan Akta Sidang Sinode GKJ XXV 2009 Artikel 75 yang menyatakan bahwa: "Setelah membahas usul dari (1) Klasis Banyumas Utara tentang revisi liturgi ibadah. (2) Purworejo agar sinode mengkaji secara serius penggunaan bacaan leksionari. (3) Yogyakarta Selatan tentang penjelasan penggunaan bacaan leksionari di dalam liturgi. (4) Pekalongan Barat agar sinode menetapkan penggunaan bacaan leksionari dalam ibadah. (5) Semarang Timur tentang dasar penggunaan bacaan leksionari dan kaitannya dengan liturgi I, II, III. (6) Semarang Selatan tentang pengkajian ulang penggunaan leksionari. (7) Kartasura agar sinode menyusun Tata Ibadah berdasarkan bacaan leksionari dan menetapkan penggunaan simbol, warna, dan pakaian liturgi. (8) Boyolali agar sinode mempersiapkan liturgi yang mengarah kepada bacaan leksionari. (9) Klaten Barat tentang meng-gunaan liturgi secara sinodal yang menggunakan bacaan leksionari dan tambahan dokumen gereja pada kalender gerejawi. (10) Pertanyaan dari Klasis Semarang Timur tentang kalender gerejawi; sidang mempertimbang-kan (1) Keterlibatan GKJ dalam Gerakan Oikumene melalui keesaan bacaan, (2) Sejarah keselamatan yang utuh diharapkan mampu dihayati oleh jemaat, maka sidang memutuskan: (1) Menetapkan penggunaan bacaan leksionari (Revised Commond Lectionary) dalam ibadah GKJ. (2) Menugasi tim liturgi sinode untuk menyelenggarakan kajian tentang bacaan leksionari dan menyusun tata ibadah yang sesuai bagi penggunaan bacaan leksionari dalam tata ibadah GKJ dengan mempertimbangkan kalender gerejawi, kekayaan budaya, dan pergumulan lokal. (3) Memberikan kesempatan kepada tim selama 12 bulan untuk menyelesaikan kajian dan liturgi, dan disosialisasikan. (4) Hasil kajian disosialisasikan kepada jemaat oleh gereja masing-masing."

Ada beberapa hasil yang sudah bisa diwujudkan dari keputusan Sidang Sinode GKJ XXV 2009 di atas. Pertama adalah pendistribusian leksionari setiap tahun ke seluruh jemaat GKJ. Kedua, tulisan-tulisan khotbah untuk setiap peribadatan hari Minggu maupun renungan harian yang disusun oleh Sinode GKJ telah dibuat sesuai dengan bahan leksionari yang

\footnotetext{
${ }^{17}$ Akta Sidang Sinode GKJ XIII 1974 Artikel 153, menyatakan: "Setelah sidang membahas laporan seksi E yang telah menggumuli usul Klasis Yogyakarta Timur tentang: mengangkat tangan dalam mengucapkan I Kor 1:3 dalam liturgie kebaktian, maka sinode memutuskan: Dalam mengucapkan Firman yang tersebut dalam I Kor. 1:3 ("Kasih karunia dan damai sejahtera dari Allah, Bapa kita, dan dari Tuhan Yesus Kristus menyertai kamu ...") tidak dibenarkan dengan mengangkat tangan selain Pendeta, mengingat bahwa Firman tersebut adalah salam berkat."
} 
diambil dari Revised Commond Leksionary (RCL). Ketiga adalah dibuatnya dua buah ragam bentuk rancangan liturgi untuk penggunaan leksionari dengan penjelasan ringkas dan lengkap. ${ }^{18}$

Akhirnya, yang dimaksudkan dengan kesadaran akan kebutuhan dari pergumulan umat GKJ pada aras sinodal yang juga memiliki sifat pastoral adalah berupa nyanyian-nyanyian pujian umat, yang sesungguhnya sangat berhubungan erat dengan persoalan tantangantantangan dalam per-kembangan liturgi sekaligus tanggung jawab keberadaan umat GKJ sebagai Gereja yang dewasa, sebagimana telah dijelaskan dalam bagian sebelumnya.

Yang pasti, kesadaran akan kebutuhan dari pergumulan umat GKJ pada aras sinodal yang bersifat penggembalaan itu semakin jelas semenjak proses kehidupan peribadatan pasca pemberlakuan Liturgi GKJ baru. Tanpa harus kehilangan kekhasannya sebagai Gereja Jawa yang harus berkembang dan dapat menampung aspirasi umatnya, maka ditetapkanlah keputusan dalam beberapa Sidang Sinode GKJ untuk memperkuat peribadatan umat yang dilakukan dengan liturgi GKJ baru tersebut.

Pada Akta Sidang Sinode GKJ XXI 1994 Artikel 98, 99, 100, ditegas-kan bahwa Mazmur dan Kidung yang diubah menjadi Kidung Pasamuwan Kristen (KPK) ditetapkan sebagai nyanyian resmi di GKJ. Demikian pula dengan Kidung Pujian yang telah disusun dan waktu itu tengah diadakan perbaikan sebagai nyanyian tambahan (suplemen) bagi umat ditetapkan sebagai nyanyian resmi di GKJ. Adapun Kidung Jemaat juga boleh di-pergunakan dalam peribadatan Minggu dengan pertimbangan untuk me-numbuhkan semangat oikumene seperti anjuran Sidang Raya PGI X 1984.

Seluruh pergumulan yang berkembang atas pelaksanaan liturgi GKJ yang baru tersebut, selaras pula dengan upaya perumusan PPAGKJ yang semestinya menjadi dasar liturgi bagi umat GKJ itu sendiri. PPAGKJ yang memiliki benih jauh sebelum waktu proses perumusan yang secara pasti dilakukan setelah tersusunnya liturgi GKJ baru tersebut, ${ }^{19}$ pada akhirnya selain berusaha mempertahankan warisan ajaran iman yang dipandang masih memiliki relevansi dengan konteks kehidupan umat, ${ }^{20}$ juga mampu memperlihatkan pandangan imannya yang khas.

Kekhasan pandangan iman yang pada akhirnya dapat dimiliki oleh GKJ tersebut adalah: (1) Acuan PPAGKJ hanya Alkitab. Karena itu literatur acuan disendirikan pada Buku Penjelasan Pokok-Pokok Ajaran Gereja Kristen Jawa. (2) Titik tolak PPAGKJ berasal dari pendekatan soteriologi, di mana keselamatan dikerjakan oleh Allah. Karena itu Kristologi dipandang sebagai salah satu dari kesatuan dan puncak dari cara kerja Allah untuk menyelamatkan manusia di dalam wujud Trinitas. (3) Pandangan iman tentang Alkitab sebagai firman Tuhan. (4) Panggilan Kristen ataupun Gereja yang sesungguhnya terletak pada kegunaannya sebagai pemberitaan keselamatan dan memeliharaannya. (5) Pandangan sikap

\footnotetext{
${ }^{18}$ Sinode GKJ, Menuju Pembaruan Liturgi Gereja Kristen Jawa, (Salatiga: Percetakan Sinode GKJ, 2011), 23-24.

${ }^{19}$ Lih., Acta Synode GKD XI 1969 Artikel 78 butir (1) dan (3).

${ }^{20}$ Warisan ajaran iman yang masih dipertahankan oleh GKJ dalam pembaruan rumusan yang tersusun di dalam PPAGKJ adalah: (1) Dasa Titah. (2) Doa. (3) Pengakuan Iman Rasuli. Lih., Sinode GKJ, Pokok-Pokok Ajaran Gereja Kristen Jawa, (Salatiga: Percetakan Sinode GKJ, 1997), 6, 102-125.
} 
dan tangung jawab orang percaya di tengah dunia dengan berbagai macam kenyataan bentuk dan perkembangan kehidupan manusia, yang meliputi sikap terhadap: a) Ke-hidupan di dunia. b) Etika. c) Alam. d) Kebudayaan. e) Ilmu pengetahuan teknologi dan teknik. f) Sekularisme. g) Negara. h) Agama-agama. ${ }^{21}$

\section{Metode Penelitian}

Metode yang dipergunakan dalam penelitian ini adalah deskriptif analitis. Adapun obyek di dalam penelitian ini adalah dokumen-dokumen sejarah pandangan dan pemahaman yang menjadi sumber ataupun yang berhubungan dengan rumusan liturgi yang dipergunakan di dalam peribadatan umat GKJ. Sedangkan jenis penelitian yang dilakukan adalah penelitian kepustakaan. Adapun dokumen yang menjadi data analisis di sini dibedakan menjadi data primer dan data sekunder.

Data primer meliputi dokumen-dokumen artikel-artikel akta Sidang Sinode GKJ yang pertama (1931) hingga terakhir (2012), buku-buku liturgi beserta dengan rumusan teologis yang dimiliki oleh GKJ. Sedangkan data sekunder di dalam penelitian ini adalah buku-buku kajian sejarah mengenai GKJ, catatan-catatan lain seputar sejarah beserta issu-issu penting terkait persidangan sinode yang dilakukan oleh GKJ. Adapun data sekunder lain sebagai pendukung atau pelengkap adalah hasil wawancara dari narasumber yang berhubungan dengan rumusan liturgi GKJ itu sendiri. Setelah diadakan pemilahan terhadap dokumendokumen tersebut, data yang didapatkan dirangkai dalam bentuk susunan menurut jenis-jenis atau pokok-pokok permasalahan masing-masing sehingga menjadi kerangka objek penelitian yang jelas.

\section{Hasil Dan Pembahasan}

\section{Makna Penting Rangkaian Susunan Rumusan Liturgi GKJ}

Menurut data yang ditemukan pada bagian upaya pengembangan liturgi GKJ, makna penting di dalam rumusan liturgi adalah sebagai ungkapan perjumpaan umat dengan Tuhan. Dalam PPAGKJ, ibadah sebagai perjumpaan antara Tuhan dengan umatNya itu dimengerti sebagai tindakan dramatis simbolis. ${ }^{22}$ Perjumpaan tersebut menjadi wahana dialog antara Tuhan dengan umat. Percakapan dua arah dalam iman antara Tuhan dengan umat itu merupakan perwujudan actus aparte Dei, actus aparte populi, secara timbal balik. Tindakan pada liturgi itu disebut juga katabatis dan anabatis. ${ }^{23}$ Inti ungkapan drama simbolis pada tata peribadahan GKJ itu adalah Tuhan menyatakan kasih karuniaNya dengan karya penyelamatan dan firman bagi umat yang diberi lambang sakramen, kemudian mereka tanggapi dengan pengakuan dosa, pujian, pengakuan iman, persembahan, doa syukur dan syafaat, maupun kesanggupan umat di bawah kedaulatan-Nya dengan rupa Roh yang bekerja atas segenap

\footnotetext{
${ }^{21}$ Band., Sinode GKJ, Pokok-Pokok Ajaran Gereja Kristen Jawa, 7-125., Sinode GKJ, Pokok-Pokok Ajaran Gereja Kristen Jawa Edisi 2005, (Salatiga: Percetakan Sinode GKJ, 2009), 1-101., Akta Sidang Sinode GKJ Terbatas 1996 Artikel 24.

${ }^{22}$ Sinode GKJ, Pokok-Pokok Ajaran Gereja Kristen Jawa, 51-52.

${ }^{23}$ Martasudjita, Liturgi, 26-30
} 
pribadi mereka (epiklese). ${ }^{24}$ Tekanan atas kedaulatan kehendak Tuhan melalui firmaNya itu menjadikan pengajaran menonjol dalam liturgi GKJ. Firman Tuhan harus diterima dengan baik oleh umat. Karena itu pengajaran dituntut penyampaian yang jelas, sehingga mendorong penggunaan cara lisan sistematis dan lugas.

Asas pengertian yang terdapat pada rangkaian susunan rumusan liturgi GKJ tersebut disandingkan dengan makna tata upacara kepercayaan Jawa terkait dengan pandangan teologi kontekstual dapat dikatakan memiliki titik pertemuan dengan pandangan hidup atau pandangan dunia setempat. Artinya makna liturgi GKJ tersebut bisa dipahami menurut adat keagamaan masya-rakat Jawa yang pada dasarnya juga mewujudkan asas perjumpaan umat dengan Tuhan Maha Kuasa. Pada tataran ini, penafsiran maupun pemaknaan tentang tindakan pelaksanaan liturgi GKJ ke dalam pemahaman umat yang telah mengakar dan dibentuk oleh budaya mereka masuk pada salah satu dari empat unsur penting berteologi kontekstual, yaitu unsur yang meliputi kategori-kategori etis. Di tengah universalitas Injil, makna tata upacara kepercayaan Jawa sebagai liturgi masyarakat sesungguhnya tidak memperlihatkan kedudukan lebih rendah, melainkan memiliki nilai yang dapat disejajarkan dengan liturgi GKJ.

Perbedaan kenyataan wujud komunikasi dalam liturgi GKJ dan liturgi Jawa tersebut menurut pokok pengertian teologi kontekstual bukannya tidak memiliki arti apapun lagi ataupun bukannya tidak dapat lagi dilakukan metode pendekatan sebagai kontekstualisasi. Berdasarkan persamaan nilai-nilai maupun bentuk-bentuknya, adat budaya keagamaan masyarakat Jawa dapat dijadikan wahana menanamkan gagasan-gagasan dasar universalitas Kristus, sehingga dalam tuntutan misteri inkarnasi Sabda Allah atas diri Gereja tidak menjadikan dirinya orang asing bagi dunia atau bangsa dan budaya tempat berpijak tanpa kehilangan isi dasar liturginya, tidak memper-lihatkan kesan pertemuan dengan Tuhan yang dibuat-buat, serta tidak men-jadi barang mentah tanpa bisa dikenyam dan dimengerti dengan utuh melalui cara pandang yang mengakar pada budaya serta pergumulan umat sebagai bagian masyarakat. Namun, dengan pemikiran teologi kontekstual tersebut persoalan katabatis dalam liturgi GKJ kini menjadi terlihat. Memang di PPAGKJ dinyatakan cukup tegas bahwa sikap Gereja terhadap kebudayaan adalah mengambil dan menggunakan kulit atau wadahnya dengan cara mengeluarkan serta mengganti isinya apabila tidak sesuai dengan iman. $^{25}$ Akan tetapi dalam liturgi peribadahan sebagai salah satu kenyataan kehidupan umat, penerapannya masih sebatas wujud dan cara kebiasaan-kebiasaan ala GKN. Karena itu terlepas dari doktrin ataupun kuatnya pengaruh politik di beberapa kalangan GKJ, liturgi GKJ menjadi kurang memiliki ciri kontekstual dari dirinya sendiri sebagai bagian dari masyarakat Jawa. Alasan ini dimungkinkan juga menjadi penyebab adanya artikel-artikel yang mengangkat pentingnya budaya Jawa pada persidangan sinode GKJ, ataupun dualisme wajah umat GKJ ketika menghadapi tuntutan tradisi Gereja sekaligus tradisi budaya pembentuk kepribadian masyarakat-nya. Apa yang diperoleh dari Gereja terkesan kurang memberi

\footnotetext{
${ }^{24}$ Duba dan Sidjabat, Asas-Asas Kebaktian Alkitabiah dan Protestan, 23-39.

${ }^{25}$ Sinode GKJ, Pokok-Pokok Ajaran Gereja Kristen Jawa, 59-60.
} 
pengertian maupun kemampuan umat untuk menerima pengenalan dan sapaan Tuhan, sehingga slamêtan sebagai wujud akar budaya umat dijadikan pelengkap.

\section{Sumber-Sumber Pokok Acuan Rumusan Liturgi GKJ}

Berdasarkan kajian data, sumber-sumber pokok yang menjadi acuan rumusan liturgi GKJ dapat dipilah ke dalam dua wujud, Wujud pertama, unsur liturgi yang berasal dari warisan GKN terkait kebiasaan Calvin yang dipakai pada Sinode Dordrecht. Wujud kedua, persoalanpersoalan penting umat GKJ yang meliputi perlunya partisipasi umat di dalam liturgi peribadahan dan persoalan pengaruh ajaran karismatik terhadap kehidupan umat, serta pentingnya kebudayaan Jawa bagi kehidupan umat terkait adat dan seni, dengan kebutuhan perangkat maupun kelengkapan pokok bagi pe-laksanaan liturgi.

Data tersebut ditemukan dari penjelasan prinsip liturgi GKJ, yang menyatakan bahwa sumber yang diambil untuk rumusan votum adalah Mazmur 124:8, seperti yang diwajibkan oleh Sinode Dordrecht (1574) dari kebiasaan Calvin. Kebiasaan itu berisi penyataan dasar bahwa peribadahan umat terjadi oleh pertolongan Tuhan Pencipta langit dan bumi. Terlepas dari konteks politik yang pernah terjadi di tengah sejarah Gereja Belanda maupun konteks sejarah ayat dari Alkitab itu sendiri, ditilik dari pandangan Jawa maka warisan GKN tersebut secara teologis memiliki kesejajaran. Orang-orang Jawa mengenal Tuhan dengan sebutan "Gûsti Íngkang Mâhâ Kawâsâ, Íngkang Nitahakên langìt lan bumi, Papan lan Tukìng pitulûng”. Bahkan, pengertian tersebut dalam liturgi GKJ berbahasa Jawa dijadikan terjemahan rumusan votum itu: "Pitulungan kitâ wôntên ing Asmanipûn GÛSTI/YEHUWAH, Íngkang Nitahakên langit lan bumi" (Pertolongan kita ada dalam Nama TUHAN, Yang menjadikan langit dan bumi).

Dalam kajian teologi kontekstual, pengertian dalam pemahaman votum di atas merupakan nilai-nilai yang memiliki titik temu atau kesamaan untuk menanamkan inti teologi atau gagasan-gagasan dasar dari liturgi peribadahan GKJ. Tentu saja titik temu atau kesamaan nilai tersebut merupakan hasil dari langkah penafsiran dan pemaknaan GKJ dalam ber-teologi kontekstual. Dengan asas-asas penyesuaian liturgi, maka pengertian dasar misteri inkarnasi Sabda sebagai penyataan Tuhan dalam darah maupun daging manusia sepenuhnya dan khas dapat dikenali pula oleh umatNya dengan ciri bahasa budaya seperti yang ada di dalam kehidupan masyarakat umat GKJ. Bahasa yang khas tersebut memungkinkan terjadinya pertemuan dan percakapan umat dengan Tuhan ataupun sebaliknya secara pribadi dan agung tidak dibuat-buat. Bahkan melalui bahasa pribumi itu setiap istilah maupun lambang dan tanda liturgi mestinya bukan lagi barang mentah yang sulit dikenyam dan dimengerti karena dapat terkomunikasikan dengan utuh. Dengan demikian seruan pengakuan tentang Tuhan Pencipta langit dan bumi sebagai Penolong dan dasar peribadahan umat GKJ dapat dikatakan sebagai langkah kontekstualisasi yang positif berupa translasi serta partisipasi. Unsur-unsur yang menjadi nilai-nilai mendasar tentang Tuhan menurut budaya Jawa dijadikan pendekatan pempribumian untuk menanamkan gagasan mendasar sehingga dapat diterima umat secara lebih luas, bahkan menjadi sasaran berteologi liturgi GKJ yang diperoleh dari GKN. Namun, bila langkah bagi tata peribadahan GKJ masih sebatas trans-lasi ataupun partisipasi maka 
jatidiri GKJ pada liturginya belum nampak. Sebab meskipun langkah-langkah kontekstualisasi di atas positif, tetapi bukan langkah rekonstruksi yang menjadikan teologi itu sendiri sebagai sasaran dan tujuan pembaruan dan perubahan.

\section{Persoalan-Persoalan Umat dalam Pelaksanaan Liturgi GKJ}

Pada pembahasan data, beberapa persoalan utama yang menjadi dasar perumusan liturgi GKJ yang ditemukan dalam pelaksanaan per-ibadahan umat adalah persoalan liturgi yang dirasa membosankan karena kurangnya peran serta umat, maupun penggunaan bahasa Jawa sebagai bahasa pengantar peribadahan yang mulai susah ditangkap para kaum muda sehingga perlu disertakan bahasa Indonesia yang makin terbiasa bagi mereka. Selain itu ada pula persoalan pengaruh ajaran kharismatik karena perjumpaan umat dengan pola Kekristenan di luar perhimpunan mereka. Berbagai persoalan tersebut ditanggapi Gereja dengan menerbitkan liturgi lengkap dengan variasi beserta keterangan penting terkait makna, asas, unsur-unsur, maupun tata susunannya, yang dikembangkan dari liturgi formula I sebagai liturgi GKJ awal. Liturgi-liturgi variasi itu adalah liturgi formula II dan liturgi formula III, atau yang disebut dalam sumber data sebagai Liturgi Minggu Ke-2 dan Liturgi Minggu Ke-3. Susunan kedua liturgi variasi tersebut terdapat penataan teknis peran umat dalam pe-laksanaan liturgi. Rancangannya ialah supaya liturgi tidak dilakukan hanya secara tata lahiriah saja, tetapi dimengerti dan dihayati secara utuh, sehingga perlu adanya tanggapan aktif dari umat sebagai bentuk dialog suatu peristiwa pertemuan dengan Tuhan. Pemberian ruang untuk memberikan keseimbangan peran serta umat pada rancangan liturgi formula II maupun liturgi formula III tersebut tidak terpisahkan dengan maksud yang disampai-kan terkait dengan karunia Roh Kudus di tengah peribadahan pada pen-jelasan di buku liturgi itu. Kebebasan penyataan karunia Roh Kudus dalam bahasa lidah harus dipahami bukan demo atau atraksi umat, namun sebagai penyataan kehendak Tuhan dalam rangka mendukung terwujudnya gagasan mendasar liturgi melalui bahasa komunikasi yang akhirnya harus dimengerti umat dan memberi dampak pembangunan kehidupan iman mereka.

Ditilik dari konteks budaya Jawa, gagasan-gagasan mendasar liturgi GKJ atas persoalanpersoalan tersebut bisa dicermati dengan tindakan-tindakan yang dilakukan pada upacara kepercayaan masyarakat Jawa itu sendiri. Bentuk-bentuk keterlibatan umat dalam pelaksanaan ritual Jawa secara umum intinya sama dengan bagian-bagian yang ditata pada liturgi GKJ. Ada rupa-rupa pujian, sajian, doa, bahkan terkadang atraksi sebagai kesatuan rangkaian liturgi. Apapun tindakan umat di dalam keterlibatannya di tengah upacara keagamaan masyarakat Jawa itu, semua dihubungkan dengan bahasa Jawa yang menjadi sarana komunikasi baku bagi kehidupan umat. Dengan peran serta umat dalam bentuk-bentuk dialog maupun atraksi, orang-orang Jawa dapat menghayati gagasan-gagasan tentang Tuhan yang diyakini ada dengan segala karya kuasa dan berdaulat atas kehidupan ciptaanNya. Demikian pula dengan penggunaan bahasa Jawa, umat menjadi semakin menerima akan pengertian nilai-nilai gagasan-gagasan mendasar yang terangkai dalam liturgi mereka.

Persoalan kedua sebagai sumber liturgi-liturgi variatif di atas adalah pentingnya kebudayaan Jawa bagi kehidupan umat terkait adat upacara kepercayaan dan seni, dengan 
kebutuhan perangkat maupun kelengkapan pelaksanaan liturgi. Menurut data, kebutuhankebutuhan penting akan adat istiadat dan seni tersebut berupa adat peringatan orang meninggal, peringatan masa kehamilan maupun masa setelah kelahiran, sunatan, pernikahan, seni wayang, penggunaan gamêlan dan têmbang dalam pelaksanaan liturgi. Adapun kebutuhan perangkat maupun kelengkapan pokok untuk pelaksanaan liturgi sendiri adalah berupa pakaian beserta barang-barang penyerta untuk pelayanan pendeta, dan penyampaian bacaan Alkitab secara leksionari.

Aneka kebudayaan adat ritual penting bagi masyarakat Jawa di atas sarat dengan lambang-lambang, aturan-aturan dan petunjuk-petunjuk kehidupan langsung ataupun tersamar. Apapun bentuknya, wujud-wujud kebudayaan Jawa itu mengungkapkan gagasan tentang keberadaan Tuhan Maha Kuasa, Sumber karunia kehidupan dan keselamatan yang mesti disembah, layak mendapat persembahan, dipuja, dan dijadikan Penolong atas segala kejadian dalam hidup manusia. Karena itu, pada hakikat makna mendasar dari aneka adat peringatan dalam budaya Jawa beserta rangkaian kegiatannya tersebut masih tetap memiliki titik temu atau kesamaan nilai yang dapat menjadi sarana untuk menanamkan gagasangagasan mendasar liturgi GKJ melalui pendekatan-pendekatan penyesuaian yang mengena dan berdaya guna bagi missi iman di dalam kehidupan umat dengan model kompromi, adaptasi, dan asimilasi; atau yang disebut pula sebagai pendekatan indigenisasi dengan langkah translasi, partisipasi, dan rekonstruksi sebagai pendekatan kontekstual.

Berpijak dari pemikiran penyesuaian liturgi atas beberapa sumber-sumber acuan praksis iman umat GKJ kedua itu, tampaknya susunan liturgi yang kemudian diterbitkan GKJ belum memberikan peluang bagi adat kebudayaan Jawa. Dari bahasan data, iringan kesenian Jawa belum sepenuh-nya bisa diterima untuk liturgi GKJ. Selain seni nyanyian setengah hati karena terkesan cenderung berjiwa melodi bangsa Barat, seni gamêlan, bêksâ, wayang terlihat masih menjadi persoalan sulit untuk dilibatkan dalam liturgi GKJ. Kenyataan itu tampak pada nyanyian peribadahan umat berbahasa Jawa yang miskin irama pelôg maupun irama slendro khas Jawa, dibandingkan dengan yang berirama pentatonik dan notabene menurut pengungkapan data memang digubah oleh van Dijk ataupun terjemahan dari nyanyian Gereja Eropa abad pertengahan susunan I. L. Kijne, terbitan Stichting Geestelijke Liederen uit de Schat van de Kerk der eeuwen-s'Gravenhage. Sulitnya penyerapan seni budaya Jawa pada liturgi GKJ ter-sebut menunjukkan bahwa meskipun telah memiliki pandangan di PPAGKJ tentang berteologi kontekstual, tetapi perwujudannya di dalam liturgi masih belum menyentuh kehidupan kontekstual Jawa.

Kesulitan liturgi GKJ dalam menyerap bentuk-bentuk kebudayaan Jawa tersebut dimungkinkan karena kebiasaan Calvin yang menjadi acuan berliturgi bagi GKJ diterima seutuhnya dan ditegaskan pula dalam sidang Sinode GKJ IX tahun 1964. Sikap Calvin terhadap peran kesenian, seperti musik di dalam pelaksanaan liturgi umat begitu hati-hati. Meskipun musik itu baik untuk dipakai dalam tata peribadahan umat, tetapi peran musik tidak boleh menggeser pengarahan dan penyerahan hati umat kepada Tuhan (sursum corda). ${ }^{26}$

\footnotetext{
${ }^{26}$ De Jonge, Apa Itu Calvinisme?, 180-185.
} 
Karena itu kesederhanaan yang diyakini Calvin memiliki kesamaan dengan Umat Kristen Mula-Mula ditekankan. Meskipun cukup ambigu tetapi seni vokal seperti koor, akapela, taise, dan lain sebagainya lebih dikembangkan di tengah peran umat dalam berliturgi daripada seni alat musik. Dengan pertibangan kesederhanaan bias itulah, maka piano ataupun orgel dengan irama keagungan saja yang bisa dipakai dalam pelaksanaan tata peribadahan umat.

Kurangnya peluang liturgi GKJ bagi bentuk-bentuk kebudayaan Jawa itu juga terjadi pada nilai-nilai ajaran atau faham melalui lambang-lambang dalam upacara-upacara adat yang telah disebutkan di atas. Peringatan kematian, kehidupan yang dimulai dari kandungan sampai kelahiran, maupun tahap-tahap proses tujuan kehidupan manusia yang selalu dihayati orangorang Jawa dalam rangka menuju keselamatan belum mendapat sentuhan tepat oleh makna penting liturgi GKJ seutuhnya, yang sesungguh-nya tidak terpisah dengan sakramen baptis maupun sakramen perjamuan, sebagaimana dinyatakan dalam penjelasan arti dan isi pada buku liturgi GKJ itu sendiri. Sakramen sebagai pusat liturgi GKJ memiliki kemiripan nilainilai mendasar dengan adat peringatan Jawa di atas, yaitu peringatan kematian dan kebangkitan Yesus Kristus untuk menebus, menyucikan, menyelamatkan, memberikan kelahiran dan kehidupan baru bagi orang bertobat dan percaya, yang dilambangkan dengan air, anggur, dan roti.

\section{Lambang-Lambang Pokok yang Dipergunakan bagi Pelaksanaan Liturgi GKJ}

Menurut himpunan data, yang digunakan di dalam pelaksanaan liturgi GKJ secara langsung ada dua lambang. Pertama, Alkitab dengan makna sebagai firman Allah, sumber pengajaran, maupun pedoman iman, sekaligus kedaulatan Tuhan atas umat, seperti dinyatakan pada PPAGKJ sehingga diperlakukan dan ditempatkan sebagai tolok ukur kebenaran berjenjang tertinggi. Sebagai lambang di dalam peribadahan GKJ, Alkitab yang dibawa Penatua diserahkan kepada Pendeta atau Pengajar di depan mimbar yang ada di tengah kehadiran umat untuk memimpin jalannya peribadahan. Kedua, pengangkatan tangan pemimpin dalam penyampaian salam di awal liturgi GKJ dan berkat pada akhir tata peribadahan itu. Sedangkan lambang-lambang pokok lain dapat diketahui secara tersirat pada sumber-sumber data yang sama dengan di atas maupun pratelan (rumusan) sakramen. Dokumen-dokumen itu menyebutkan tentang sakramen baptis maupun sakramen perjamuan. Khusus sakramen perjamuan, pelaksanaannya dilambangkan sesuai dengan kebiasaan GKN, yaitu air yang bermakna pembasuhan atau penyucian, anggur dengan makna darah Yesus Kristus yang dipandang sama seperti darah korban anak domba Paskah sebagai pengudusan sekaligus meterai janji penyelamatan oleh Allah, dan roti yang bermakna tubuh Yesus Kristus yang dianggap sama dengan tubuh anak domba Paskah yang dibagikan sebagai korban penebusan; sekaligus alat pengenang.

Dipersandingkan dengan aneka lambang yang terdapat pada upacara-upacara adat kepercayaan Jawa, secara umum juga memiliki makna nilai-nilai mendasar yang sama. Lambang yang biasa dikenal masyarakat Jawa dalam berbagai adat slamêtan itu adalah tumpêng lengkap dengan ingkûng, bancaan, banyu tâwâ, maupun banyu kêmbang. Semuanya itu mengandung falsafah ajaran, pedoman dan ketentuan-ketentuan kehidupan bagi umat, 
serta kedaulatan Tuhan atas hidup mereka, peringatan, penebusan, maupun penyucian. Upaya membuat titik temu atau kesamaan nilai-nilai tersebut ada dua lambang dalam liturgi GKJ yang berbeda dengan lambang dalam slamêtan. Pertama, Alkitab sebagai lambang firman dan kedaulatan Tuhan, serta ajaran, petunjuk, maupun pedoman kehidupan umat. Masyarakat Jawa kurang mengenal lambang berbentuk pustaka tulisan seperti yang digunakan dalam liturgi GKJ. Makna-makna itu mereka kenal dari berbagai ubârampe yang menyatu sebagai lambang pada tumpêng lengkap. Kedua, anggur sebagai lambang darah yang tidak hanya bermakna penebusan tetapi juga meterai janji keselamatan dari Tuhan. Dibandingkan dengan roti, lambang, makna, dan padanan anggur itu tidak dikenal dalam pemikiran budaya Jawa.

Meskipun demikian, titik temu atau kesamaan nilai-nilai penting yang diperoleh di atas merupakan khazanah pengetahuan yang dapat digunakan oleh GKJ untuk mengakarkan iman sebagai teologi kontekstual, atau yang diistilahkan Sedmark dengan teologi lokal, khas budaya Jawa. Namun dengan pernyataan seluruh data yang telah disebutkan, pelayanan sakramen perjamuan tetap menggunakan lambang roti dan anggur. Kenyataan itu memberi dugaan adanya masalah yang tidak mudah untuk mencari padanan lambang-lambang sakramen perjamuan sebagai upaya penyesuaian bagi pengakaran gagasan-gagasan iman pada liturgi GKJ, khususnya anggur. Karena itu penggunaan kedua lambang tadi pada liturgi GKJ barulah merupakan tindakan transplantasi, atau disebut juga sebagai pendekatan kompromi. Mengingat perbedaan nilai yang sulit maka dilakukan ke-sepahaman, sehingga lambanglambang yang didapatkan dari ajaran Gereja Belanda tadi dimasukkan dan dipergunakan sepenuhnya oleh GKJ bagi tata peribadahan umat yang berpandangan hidup Jawa. Belum ada tindakan partisipasi, bahkan rekonstruksi terhadap budaya maupun teologi GKJ sebagai langkah menuju teologi kontekstual, khususnya dalam liturgi.

\section{Kelengkapan Pokok yang Dipergunakan bagi Pelaksanaan Liturgi GKJ}

Dari data yang dihimpun pada bab sebelumnya dinyatakan ada dua rupa. Pertama, pakaian pendeta beserta dengan kelengkapannya, yaitu jubah pengajar (toga), dasi (kolar), dan selendang bahu (stola). Menurut data dijelaskan pula bahwa kelengkapan pakaian pendeta yang dianggap pokok itu digunakan untuk pelayanan-pelayanan khusus, yaitu pelayanan sakramen, pelayanan ibadah hari raya Kristen, pelayanan peneguhan dan pemberkatan, serta peresmian secara gerejawi (termasuk pernikahan), bahkan sempat diseyogyakan supaya digunakan juga pada acara pelayanan persekutuan doa syukur (bidstonde) dan pelayanan pemakaman. Apapun penggunaannya, kelengkapan pakaian pendeta itu tidak mengubah arti mendasar bahwa yang mengenakannya adalah pengajar gerejawi.

Kedua, daftar bacaan dari Alkitab yang saling berhubungan secara berkesinambungan (lectio continua). Menurut data petunjuk pada buku penggunaan leksionari dalam pelaksanaan liturgi GKJ, leksionari dirancang agar bisa melibatkan umat secara bergantian dengan kreatif bersama petugas ataupun pemimpin ibadah. Cara itu bertujuan supaya firman Tuhan dapat mudah diterima dan dihayati umat secara aktif.

Disejajarkan dengan kebudayaan Jawa pakaian pengajar atau pemimpin dalam upacara kepercayaan Jawa selama ini cenderung tidak tentu. Walaupun ada falsafah Jawa yang 
dikembangkan melalui aneka corak dan warna dalam bentuk-bentuk pakaian berdasarkan faham jagad gêdhe dan jagad cilik melalui ajaran kiblat papat limâ pancêr, tetapi secara lahiriah tidak menjadi sesuatu yang menonjol di jaman sekarang, dan kini mengalami perubahan terpadu dari bentuk kêmbên (pakaian kain berlilit) ke bentuk kêbaya (baju wanita adat Jawa sekarang oleh pengaruh China kuno) dan sorjan/beskap (baju pria adat Jawa sekarang oleh pengaruh Eropa di masa penjajahan). Sedangkan pakaian bawah tetap memakai kain yang dililit, yang disebut jarit atau sinjang, polos ataupun corak dan warna ber-garis maupun batik.

Ditinjau dari pemaknaan pakaian tersebut, baju pelayanan pendeta dalam pelaksanaan liturgi GKJ jelas berbeda dengan pakaian adat Jawa. Jubah pendeta GKJ itu berarti tanda bagi seorang pengajar, sementara pakaian adat Jawa bukan sekedar tanda pengenanya adalah orang Jawa, tetapi juga merupakan lambang yang mencerminkan pandangan kehidupan-nya. Karena itu, bila penggunaan toga pada liturgi GKJ hanya sebatas tanda pengenal jabatan tugas seseorang di dalam pelaksanaan tata peribadahan umat, maka pakaian liturgis itu belum memiliki muatan teologi kontekstual. Agar memiliki sentuhan kontekstual Jawa, bisa menggunakan cara pen-dekatan asimilasi yang meng-ambil sesuatu yang baik dan berguna dari pengertian mengenai pakaian adat Jawa untuk menanamkan nilai-nilai Injili. Bahkan bisa juga menggunakan masalah pakaian tersebut sebagai sasaran partisipasi berteologi GKJ, serta memampukannya untuk mengadakan rekonstruksi terhadap teologi GKJ itu sendiri sehingga memunculkan jatidiri relevan yang khas berdasarkan sejarah dan kebudayaan Jawa.

Sedangkan keberadaan lectio continua sebagai tata cara pembacaan teks-teks suci memungkinkan untuk dilakukan dalam liturgi GKJ. Sebab umat memiliki Alkitab sebagai pustaka tulisan yang cenderung selalu tersedia. Karena itu, apabila pembacaan teks-teks suci tersebut dicari per-samaannya dalam adat upacara kepercayaan Jawa memang tidak tersedia. Akan tetapi bila persoalan itu dicari hakikatnya, maka dapat ditemukan dalam perkumpulan gêgulang. Bahkan gêgulang memiliki ciri unik. Pembacaan teks-teks puisi, sejarah dan kisah, maupun himpunan kata-kata serta nasihat bijak leluhur adiluhûng sebagai ajaran kebenaran nan keramat bagi kehidupan orang-orang Jawa itu tidak hanya diucapankan biasa, tetapi dengan lantunan lagu khas Jawa, dan tidak jarang dilakukan secara bersahutan. Apabila tata peribadahan GKJ dapat mempertimbangkan dan mengolah kebiasaan penyampaian ajaran Jawa di atas sebagai cara berteologi dan menanamankan gagasan-gagasan mendasarnya melalui langkah translasi, partisipasi, rekonstruksi, maupun pendekatan model kom-promi, adaptasi, dan asimilasi, maka tata peribadahan GKJ akan menjadi liturgi kontekstual yang mudah diresapi dan dimengerti oleh umat dengan budaya Jawa yang menghidupi dan membentuknya. Bahkan dimungkinkan juga diterima dan menjadi bagian dari adat masyarakatnya, seperti gagasan yang terdapat pada ritual communio sanctorum di Sendang Sono, Ganjuran, maupun di makam Romo Frans van Lith, Muntilan. ${ }^{27}$

${ }^{27}$ Albertus Bagus Laksana, Journeying to God in Communion with the Other: A Comparative Theological Study of the Muslim and Catholic Pilgrimage Traditions in South Central Java and their Contributions to the Catholic Theology of Communio Sanctorum, Doctoral Dissertation (Boston: Boston College 2011), 187-426. 


\section{Kesimpulan}

Kesimpulan akhir dari penelitian tentang teologi kontekstual berbasis budaya Jawa terhadap liturgi GKJ adalah ada kesulitan besar pada tata peribadahan GKJ di dalam menanamkan gagasan iman beserta nilai-nilainya sehingga dapat diterima dan dihayati umat di dalam kehidupan yang berakar pada kebudayaannya, yaitu budaya Jawa. Akar yang telah menguat secara mapan pada warisan pandangan dan tradisi GKN membuat liturgi GKJ sulit tersentuh dan menyentuh doktrin GKJ masa kini maupun kenyataan dunia kehidupan umat yang menjadi bagian masyarakat yang dibentuk oleh budaya Jawa. Sulitnya persentuhanpersentuhan itu tercermin dalam pandangan dan sikap GKJ terhadap wujud-wujud kebudayaan dan tradisi-tradisi Jawa di masa lalu dan di masa kini yang masih kurang tegas.

Sebagai temuan penting dari kajian ini adalah meskipun liturgi GKJ merupakan liturgi yang berasal dari benih Gereja Calvinis Belanda, tetapi pandangan teologis GKJ masa kini tetang liturgi memiliki hakikat makna sejajar dengan pemahaman ritual keagamaaan dalam tradisi yang terdapat pada kebudayaan masyarakat Jawa. Liturgi adalah sarana untuk mewujudkan ibadah dalam perbuatan hidup sehari-hari, sekaligus untuk menyatakan pertemuan umat dengan Allah yang memberi anugerah penyelamatan dan manusia menanggapinya. Inilah yang dapat menjadi harapan untuk pengembangan liturgi GKJ yang membumi.

\section{Rekomendasi}

Kajian telaah ini kiranya dapat menambah khazanah liturgi sebagai bagian dari teologi praktika yang bisa dijadikan perbandingan, bahkan dikembangkan lebih kanjut. Secara khusus kiranya kajian ini dapat dijadikan salah satu wacana yang mendukung pengembangan lebih lanjut dalam upaya mewujudkan harapan liturgi GKJ di tengah kehidupan umat. Seluruh kajian sosial dan budaya Jawa yang dilakukan oleh GKJ hingga saat ini kiranya dapat dirumuskan secara konkrit sebagai pandangan maupun petunjuk teknis dan pelaksanaannya sehingga cepat atau lambat mampu memberi pemahaman positif atau kritis bagi umat untuk melakukan perjumpaan yang membawa perubahan melalui dialog Injil dengan kehidupan masyarakatnya, khususnya pandangan dan wujud-wujud kebuda-yaan Jawa dalam berbagai adat-istiadatnya.

Tentu saja upaya di atas membawa konsekuensi terhadap pengertian GKJ itu sendiri. Artinya secara kritis definisi GKJ sebagai Gereja harus ditilik ulang. Kalau tidak perlu mengadakan definisi baru, maka paling tidak pengertian tentang GKJ yang sudah ada dan dipandang memadai perlu diberi klarifikasi tambahan terkait keberadaannya sebagai bagian masya-rakat dan perannya, sehingga menjadi salah satu dasar konkrit perumusan liturgi GKJ yang mengakar dalam kehidupan masyarakat dan budayanya. Bila selama ini ada modelmodel formula liturgi berbasis kebutuhan praktis di tengah peribadahan umatnya, maka GKJ juga harus memiliki model formula liturgi yang lahir dari benih pergumulan umat di tengah kehidupan masyarakat dan budayanya sebagai Gereja beridentitas.

Akhirnya, kemampuan penyesuaian liturgi GKJ menunjukkan ke-imanan Gereja yang membumi. GKJ sebagai persekutuan orang percaya yang hidup di tengah masyarakat Jawa 
hendaknya memiliki relevansi secara langsung yang memberikan kegunaan melalui perjumpaan kristis dengan dunia keagamaan setempat. Karena itu pengembangan liturgi GKJ ke depan harus menggali aneka potensi budaya yang banyak ditemukan dalam lapangan pergumulan hidup umat di tengah masyarakatnya, sehingga Gereja tidak gamang, dan umat semakin menikmati keselamatan Injil Kristus di tengah kebersamaan masyarakatnya.

\section{Referensi}

Akkta Synode Poerwokerto 1936.

Akta Sindang Sinode GKD IX 1964.

Akta Sindang Sinode GKJ XXI 1994

Akta Sindang Sinode GKJ Terbatas 1996

Akta Sindang Sinode GKJ Antara 2000

Akta Sindang Sinode GKJ XXIII 2002

Akta Sidang Sinode GKJ Antara 2004.

Akta Sindang Sinode GKJ Antara 2004

Akta Sindang Sinode GKJ XXIV 2006

Akta Sindang Sinode GKJ XXV 2009

Akta Sindang Sinode GKJ XXVI 2012

Brownlee, Malkolm. Tugas Manusia dalam Dunia Milik Tuhan: Dasar Teologis bagi

Pekerjaan Orang Kristen dalam Masyarakat, Jakarta: BPK Gunung Mulia, 1989.

GKJ, Sinode. Pokok-Pokok Ajaran Gereja Kristen Jawa, Salatiga: Percetakan Sinode GKJ, 1998

GKJ, Sinode. Liturgi Gereja Kristen Jawa, Salatiga: Percetakan Sinode, 1996

GKJ, Sinode. Pokok-Pokok Ajaran Gereja Kristen Jawa Edisi 2005, Salatiga: Percetakan Sinode GKJ, 2009.

GKJ, Sinode. Menuju Pembaruan Liturgi Gereja Kristen Jawa, Salatiga: Percetakan Sinode GKJ, 2011

GKJ, Sinode. Pokok-Pokok Ajaran Gereja Kristen Jawa, (Salatiga: Percetakan Sinode GKJ, 1997

GKJ, Sinode. Pokok-Pokok Ajaran Gereja Kristen Jawa

GKJ, Sinode. Pokok-Pokok Ajaran Gereja Kristen Jawa Edisi 2005, Salatiga: Percetakan Sinode GKJ, 2009.

Akta Sidang Sinode GKJ Terbatas 1996.

Laksana, Albertus Bagus. Journeying to God in Communion with the Other: A Comparative Theological Study of the Muslim and Catholic Pilgrimage Traditions in South Central Java and their Contributions to the Catholic Theology of Communio Sanctorum, Doctoral Dissertation (Boston: Boston College, 2011.

Rachman, Rasid Pembimbing ke dalam Sejarah Liturgi, Jakarta: BPK Gunung Mulia, 2010 